\title{
講座 第8回
}

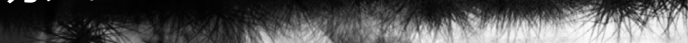

\section{0 画像の本質を引き出す

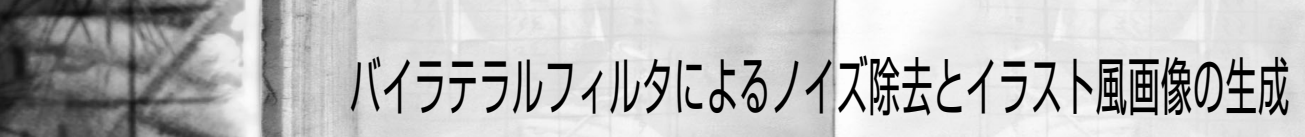

\section{1.まえがき}

エッジをぼかさずにノイズを除去するための多種多様な 非線形フィルタが考案されてきたが, ここ最近, バイラテ ラルフィルタが画像処理, コンピュータビジョンやコンピ ユータグラフィックスなど, 広い範囲で利用されてきてい る.このフィルタは, SUSANフィルタ1)や非線形ガウスフ イルタ2）などと同じものであるが，Tomasiらによるバイラ テラルフィルタという呼称 ${ }^{3)}$ が定着している.

バイラテラルというネーミングは, フィルタの重み係数 が空間座標に対応した係数と画素值に対応した係数の, 両 方を含んでいることに由来する. その点ではシグマフィル 夕4)も同じであるが，シグマフィルタのウィンドウはボッ クス型であるのに対し, バイラテラルフィルタ（以下BFと 略す)のウィンドウは性質の良いガウス関数である.

BFは当初, 通常のフィルタと同様にノイズ除去を目的に 開発されたが, その使い易さや拡張性のおかげで, 広範な 利用形態の画像処理への応用が考案されつつある.

本稿では, $\mathrm{BF}$ の特性や問題点を概説し, 種々の利用法, 特にイラスト風画像生成への応用を紹介し, 最近進みつつ ある拡張にも触れる. なお, 本稿での説明では, 記述を短 くするために, 式では空間座標は1次元だけとし, 画素值 も1次元, すなわちモノクロ画像とする, 空間座標は, 通 常の画像では2次元 (画像平面) であるが, ボリュームデー 夕や動画では3次元となり, 画素值はオプティカルフロー などでは2次元，カラー画像では3次元になる.

\section{2. バイラテラルフィルタ}

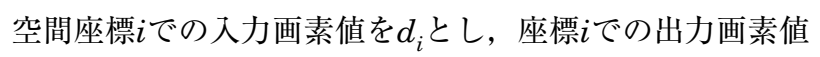
を $f_{i}$ とすると, $\mathrm{BF} て ゙ は f_{i}$ を

\footnotetext{
$\dagger$ 九州大学 大学院 芸術工学研究院

"Technologies Leading to the Next-generation Digital Cameras and Movies (8); Extracting Intrinsic Structures in Images; Noise Reduction and Generation of Illustrations by Using Bilateral Filters" by Kiichi Urahama (Faculty of Design, Kyushu University, Fukuoka)
}

$$
f_{i}=\frac{\sum_{j=i-p}^{i+p} e^{-\alpha(i-j)^{2}} e^{-\beta\left(d_{i}-d_{j}\right)^{2}} d_{j}}{\sum_{j=i-p}^{i+p} e^{-\alpha(i-j)} e^{2}}
$$

で計算する.

このBFは，以下のような長所を持つ.

(1) 非線形拡散や平均シフトフィルタ5)のような反復計算 を要せず, 動作が直感的に把握しやすい.

(2) 簡潔な単一の式だけで表され，実装しやすい.

(3) パラメータが $\alpha$ との 2 個だけで設定しやすい.

（4）ガウス性白色ノイズの除去能力とエッジの保存能力 の両方を兼ね備えている.

(5) 線形フィルタと同様に入力画素值の加重平均が出力 画素値となる.

(1) の反復不要性はウィンドウ（式 (1) では, $i-p$ から $i+p$ までの幅 $2 p+1)$ が広いことによっている. 非線形拡散法で は4近傍や8近傍だけなので, 反復によって伝播させる必要 があり，細いギャップを超えられず，反復による不安定性 や停止条件など制御が難しい問題が発生する．BFは反復が 不要なので，そのような問題が生じず，広い範囲を加重平 均するのでノイズ除去性能が高い. しかしウィンドウが広 いと計算量が増える。これについては後述するような高速 化法が開発されている.

$\mathrm{BF}$ の高いノイズ除去能力は, 式 (1) の重み係数がガウス 関数であることによる. ガウス関数は, フーリエ変換もガ ウス関数になることや，スケールスペースで因果律を満た す唯一の核関数であることなど優れた性質が多く, ウイン ドウがボックス型であるシグマフィルタよりもノイズ除去 能力が高い. また, 多次元ガウス関数は1次元ガウス関数 の積に分解できることから, 計算の効率化にも適している. BFのエッジ保存性は, 図1に示すように式 (1) の重みが 自動的に空間的に非等方になることによる. 図1左端の入 力画像 (水平面が画像平面, 縦軸は画素值) での星印の画素 での出力を考える. 図1左上の山型関数は式 $(1)$ の $e^{-\alpha(i-j)^{2}}$ (の2次元版) であり, 右上の階段状関数は $e^{-\beta\left(d_{i}-d_{j}\right)^{2}}$ である. 両者を掛け合わせると中央下の山が半分削れた形状の関数 になり，これが星印の画素での重み関数となる。このよう 


\section{画像の本質を引き出す：バイラテラルフィルタによるノイズ除去とイラスト風画像の生成}

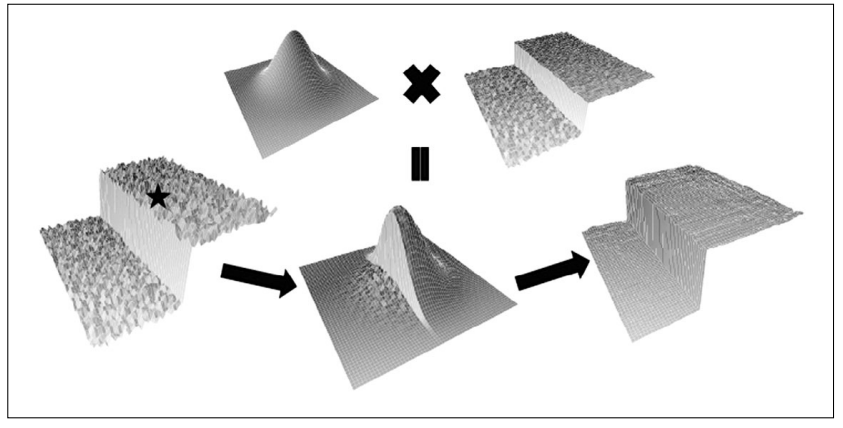

図1 BFの動作 (Durandら 25$)$ の図を再構成)

な重み関数を各画素で求めて図1左端の画像を政み込むと, エッジが保存されたままノイズが均されて右端の画像が出 力される。

このように，式 (1) の二つの重み関数 $e^{-\alpha(i-j)^{2}}$ と $e^{-\beta\left(d_{i}-d_{j}\right)^{2}}$ の それぞれは等方的であるが，それらが掛け合わされること により, 図1の下中央のように, 注目画素周辺の入力画像 の濃淡分布によって，重みが自動的に空間的に非等方にな ることがBFの特長であり，これによってエッジが保存さ れる。

なお，パラメータ $\alpha$ と $\beta$ 適切な值は, 画素值とノイズの 大きさによるが, $\beta$ の設定については, 入力画像のノイズ の標準偏差 $\sigma$ を推定して,$\beta=1 /(1.95 \sigma)$ とする経験則が提案 されている6).

最後の長所 (5) は, 加重平均の重みが空間重み $e^{-\alpha(i-j)^{2}}$ と画 素值の重み $e^{-\beta\left(d_{i}-d_{j}\right)^{2}}$ の積になっていることもあって, 順序統 計フィルタなどに比べ，後述するようにBFの拡張性が高 いことの要因である.

\section{3. 積空間での画像表現}

画像は通常, 図1左端のような関数で表される.すなわ ち画素值は, 独立変数である空間座標 $i$ (図1では画像平面 (水平面))の陽関数 $d_{i}$ として表される。これはいわば画像 平面表現であり, 画像平滑化は関数回帰問題として扱われ る.ロバスト統計による非線形フィルタはこのような観点 で議論される。

このような陽関数表現は直感的でわかりやすいが， $\mathrm{BF}$ 広い観点から理解するためには，独立変数を画像平面から, 画像平面と画素值との積空間に拡張して, 積空間座標の関 数で表現するのが有用である. 積空間とは, 画像平面に直 交する軸として画素值の次元を付け加えた直積空間である.

画像を積空間で表す直接的な方法は, 陽関数を陰関数に 変換するものであり, 図1の左端を積空間内に置かれた 3 次 元物体の表面と見るものである.この㓌関数表現では, 画 像平滑化は幾何学的な形状変形として扱われる. 非線形拡 散法の理解にはこのような幾何学的手法が有用である7 ${ }^{7}$ が, この陰関数表現では画像は厚みのない表面とみなされ，通 常の陽関数表現と本質的には違わない.

$\mathrm{BF}$ 理解するには，このような院関数ではなく，積空間 での確率分布による画像表現が有用である，以下では，画
像平面の離散座標 $に$ 加えて，画素值の離散座標を $て$ よう にギリシャ文字で表し, 積空間 $(i, \tau)$ 上の関数を $h_{i, \tau}$ のように 記す．例えば，入力画像の確率分布は $\delta_{\tau, d_{i}}$ である． $\delta_{x, y}$ は夕 ロネッカのデルタ $\left(x=y\right.$ なら $\delta_{x, y}=1, x \neq y$ なら $\left.\delta_{x, y}=0\right)$ である. すなわち空間座標 $i て ゙ は ，$ 画素值が $\tau=d_{i}$ に確率 1 で分布する のが入力画像である。このような確率分布による間接表現 は，直接的な陽関数表現よりもわかりにくいが，BFの理 解や拡張などには有用である.

このように入力画像の確率分布はデル夕関数になるが, この入力確率分布をガウスフィルタで平滑化することを考 える．積空間でのガウスフィルタは，空間座標 $i$ 方向のガウ スフィルタと画素值 $\tau$ 方向のガウスフィルタに分解できる.

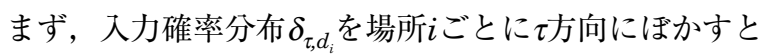

$$
c_{i, \tau}=\sum_{\varphi} e^{-\beta(\tau-\varphi)^{2}} \delta_{\varphi, d_{i}}=e^{-\beta\left(\tau-d_{j}\right)^{2}}
$$

となる. 各 $\tau$ での $c_{i, \tau}$ は1枚の画像とみなせる.ただし画素值 は0と1の間であり，入力画像の各場所iに $\tau$ 付近の值がどの 程度存在するかを表す。この画像はチャネル (Channel) と 呼ばれる ${ }^{8)}($ カーー画像でR,G,Bそれぞれのモノクロ画像を チャネルと呼ぶのと同じである).

次に，各てごとにチャネル画像をi方向にぼかすと

$$
h_{i, \tau}=\sum_{j=i-p}^{i+p} e^{-\alpha(i-j)^{2}} e^{-\beta\left(\tau-d_{j}\right)^{2}}
$$

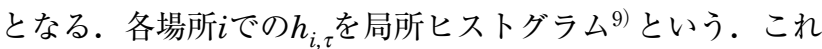
は各場所 $i の$ 近傍に $\tau$ 付近の值がどの程度存在するかを表す.

$h_{i, \tau}$ は入力画像の確率分布であるデル夕関数をぼかしたも のであり，画像のチャネル表現8)，あるいは局所無順序画 像 (Locally Orderless Image: LOI) ${ }^{9)}$ と呼ばれる. 以上の 式では $i$ は次元なので $h_{i, \tau}$ は2次元画像となる. 例えば図2上 の1次元データのLOIは図2下のようになる.

通常の画像では空間座標 $i$ は2次元であり, $h_{i, \tau}$ は 3 次元画 像となる，そのようなLOIの例を図3に示す．左が入力画像 で右がLOIである．右の1枚1枚がチャネル画像である（実 際にはチャネルは256枚ある). 最下段のチャネル画像は, 左の画像の暗い画素の確率分布であり, 最上段のチャネル 画像は明るい画素の分布である。例えば，右中段の画像は

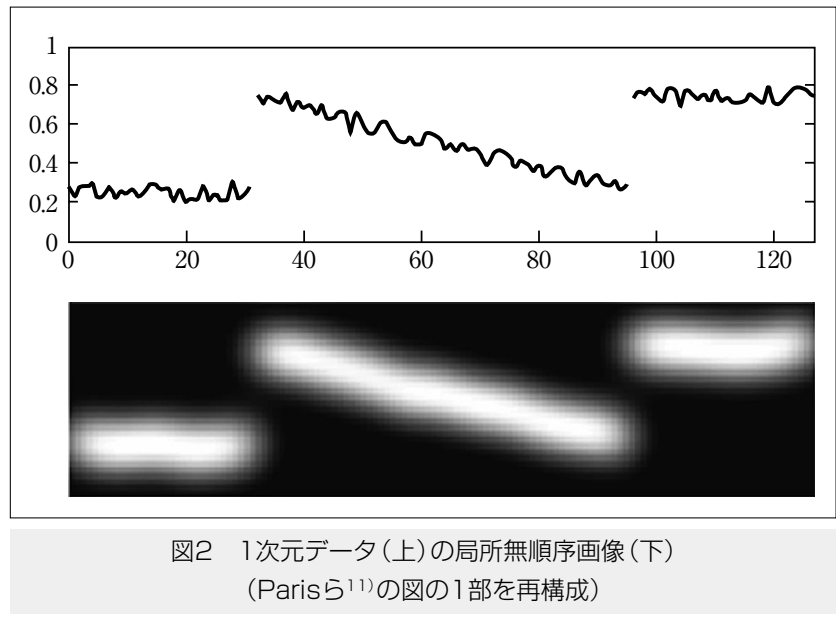

(89) 1269 


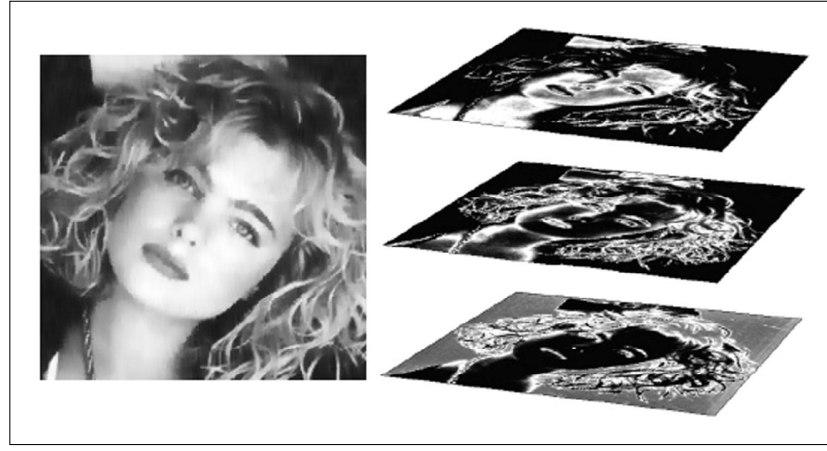

図3 2次元画像 (左)のチャネル画像 (右) $\left(P h a{ }^{10)}\right.$ の図の 1 部を再構成)

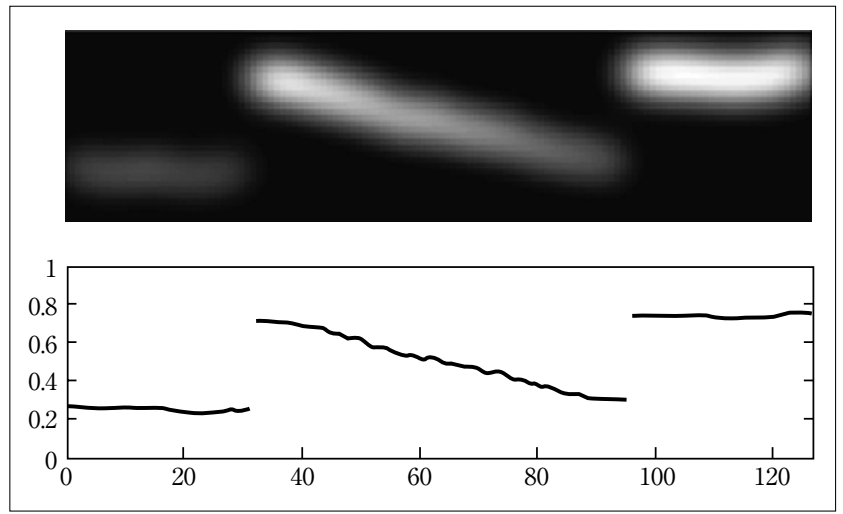

図4 図2のデータの $\tau \delta_{\tau, d_{i}}$ のLOI(上) とBFの出力 (下) (Paris5 11)の図の1部を再構成)

画素值128の確率分布であり, 白い(確率が高い) ところで は, 左の画像の画素值は128付近 (灰色)になっている.

なお, 式 (3) の $h_{i, \tau}$ の $\tau=d_{i}$ での值 $h_{i, d_{i}}$ は式 (1)の分母に一致 する. 同様に, 式 (1) の分子は積空間での関数 $\tau \delta_{\tau, d_{i}}$ のLOI の $\tau=d_{i}$ での值になる. 式 (1) の分子と分母をこのような積 空間関数で表現したものはバイラテラル格子11) と呼ばれ, 後述するようにBFの高速計算に利用される．参考のため， 図2の1次元データの $\tau \delta_{\tau, d_{i}}$ のLOIを図4上に示す.これは図 2

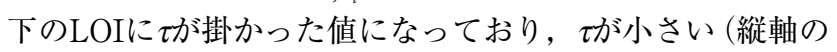
下のほう) ほど值が小さく（黒く）なっている. 図2下は式 (1) の分母, 図4上は分子であるから, 場所 $\left(i, d_{i}\right)$ での図4上 の值を，同場所の図 2 下の值で割ると式 (1) の $f_{i}$ が求まる. 図 4 下が $f_{i}$ であり, 入力 $d_{i}$ (図 2 上) からノイズが除去されて いる.

\section{4. モードフィルタ}

各場所 $i て ゙$ 局所ヒストグラムのモード (最頻值)を求める, すなわち

$$
\max _{f_{i}} E\left(f_{i}\right)=\sum_{j=i-p}^{i+p} e^{-\alpha(i-j)^{2}} e^{-\beta\left(f_{i}-d_{j}\right)^{2}}
$$

をモードフィルタという ${ }^{12)}$. 式 (4) は非線形で解析的には 解けないので反復解法で解く.

$$
\frac{d E}{d f_{i}}=-2 \beta \sum_{j=i-p}^{i+p}\left(f_{i}-d_{j}\right) e^{-\alpha(i-j)^{2}-\beta\left(f_{i}-d_{j}\right)^{2}}
$$

となるから,$d E / d f_{i}=0$ を解く逐次代入反復法は,

$$
f_{i}^{(\mu+1)}=\frac{\sum_{j=i-p}^{i+p} e^{-\alpha(i-j)^{2}} e^{-\beta\left(f_{i}^{(\mu)}-d_{j}\right)^{2}} d_{j}}{\sum_{j=i-p}^{i+p} e^{-\alpha(i-j)^{2}} e^{-\beta\left(f_{i}^{(\mu)}-d_{j}\right)^{2}}}
$$

となる. $f_{i}$ の初期值を $f_{i}^{(0)}$ として $\mu$ を1ずつ増やしながら $f_{i}^{(\mu)}$ を更新していくと式 (4) の解 (ただし局所最適解)に収束す ることが証明されている. すなわち，この反復法で局所ヒ ストグラムの局所的モードが求まる.

$f_{i}$ の初期值を $f_{i}^{(0)}=d_{i}$ とすると, 式 (6) の反復1回目の值 $f_{i}^{(1)}$ は式 (1) の $f_{i}$ になる.すなわち, $\mathrm{BF}$ はモードフィルタの反 復解法の1回目の值である.このことから $\mathrm{BF}$ の平滑化能力 はモードフィルタよりは低いと予想される.

なお，積空間での確率分布表現に基づいて， $f_{i}$ に加えて $i$ も動かして, 積空間での局所的モードに収束させる平均シ フトフィルタ ${ }^{5)}$ は，セグメンテーションにも利用される.

\section{5. 反復BF}

BFを1回かけるだけでは平滑化が不充分な場合には, BF が反復してかけられる.すなわち $f_{i}^{(0)}=d_{i}$ として

$$
f_{i}^{(\mu+1)}=\frac{\sum_{j=i-p}^{i+p} e^{-\alpha(i-j)} e^{2} e^{-\beta\left(f_{i}^{(\mu)}-f_{j}^{(\mu)}\right)^{2}} f_{j}^{(\mu)}}{\sum_{j=i-p}^{i+p} e^{-\alpha(i-j)^{2}} e^{-\beta\left(f_{i}^{(\mu)}-f_{j}^{(\mu)}\right)^{2}}}
$$

を反復する。これは，式 (4)の $d_{i}$ を $f_{i}$ に置き換えた

$$
\max _{f} E(f)=\sum_{i} \sum_{j=i-p}^{i+p} e^{-\alpha(i-j)^{2}} e^{-\beta\left(f_{i}-f_{j}\right)^{2}}
$$

の反復解法 $\left(f\right.$ は $f_{i}$ を並べたべクトル $)$ であることが次のよう にしてわかる。実際,

$$
\frac{d E}{d f_{i}}=-2 \beta \sum_{j=i-p, \neq i}^{i+p}\left(f_{i}-f_{j}\right) e^{-\alpha(i-j)^{2}-\beta\left(f_{i}-f_{j}\right)^{2}}
$$

となるから，最急上昇法

$$
f_{i}^{(\mu+1)}=f_{i}^{(\mu)}+h_{i}^{(\mu)} \partial E / \partial f_{i}^{(\mu)}
$$

において

$$
h_{i}^{(\mu)}=1 /\left(2 \beta \sum_{j=i-p}^{i+p} e^{-\alpha(i-j)^{2}} e^{-\beta\left(f_{i}^{(\mu)}-f_{j}^{(\mu)}\right)^{2}}\right)
$$

とおけば式 (7) になる.このように, 式 (6) が反復代入法 であったのに対し，式 (7) は最急上昇法である。なお，式 （8）の反復代入法は, 式 (7) とは異なる式 (分子と分母の $\sum_{j=i-p}^{i+p}$ から $j=i$ を除いたもの)になる.

このように, 式 (7) の反復BFは式 (8) の反復解法である が，式 (1) のBFは

$$
\min _{f_{i}} \sum_{j=i-p}^{i+p}\left(f_{i}-d_{j}\right)^{2} e^{-\alpha(i-j)^{2}} e^{-\beta\left(d_{i}-d_{j}\right)^{2}}
$$

の最適解である ( $\max$ と $\min$ の違いに注意). 式 (10) は $f_{i}$ の2 次式なので解は直ちに式 (1) になる.

\section{6. 拡 張 法}

$\mathrm{BF}$ は優れたフィルタであるが，問題点もいくつか指摘さ 
れている. 本章では, それらの問題点の解消法や拡張法を 紹介する.これらの拡張は, $\mathrm{BF}$ オ゙入画素值の加重平均 であり，重みが空間重みと画素值重みの積になっているこ とによっている.

\section{1 トリラテラルフィルタ}

$\mathrm{BF}$ 弱点の一つは, インパルスノイズを除去できないこ とである.そこで, インパルスノイズの検出器を第3の重 みとして追加したトリラテラル (Trilateral) フィルタが提 案されている13). $\mathrm{BF}$ 重みは, 二つの関数 $e^{-\alpha(i-j)^{2}}$ と $e^{-\beta\left(d_{i}-d_{j}\right)^{2}}$ の積なのでバイラテラルと呼ばれるが, トリラテラルフィ ルタでは重みは三つの関数の積である.

また, $\mathrm{BF}$ は入力画像を局所的な定数関数で近似する回帰 法なので, ステップエッジは保存するが, 尾根エッジや谷 エッジは丸く均されてしまう。そこで，勾配に関する第3 の重みを付け加えたトリラテラルフィルタも提案されてい $3^{14)}$.

\section{2 高次BF}

メディアンフィルタは, エッジを保存するだけで急峻化 することはないが, BFはエッジを急峻化し, エッジ保存 性よりも強いエッジ強調性をもつ. これは画像の鮮鋭化に 有用であるが, 非線形拡散と同様に, 元々エッジがないと ころにも擬似的なエッジを生じてしまうことがある。この ような擬似輪郭は, 後の図5にも見られるようにBFを反復 した場合に顕著である. 画像のイラスト化などの応用では, このような擬似輪郭はイラスト的トーン生成には有効であ るが, 通常の画像処理目的には有害であり, イラスト風画 像でも不要なエッジが増えるのは望ましくない.

そこで, このような階段効果の解消法として, 高次BFが 提案されている ${ }^{15)}$. 式 (1) のBFは, 入力画像に局所的な0次 (定数) 関数をあてはめる関数回帰法で, 統計論でカーネル 回帰と呼ばれる手法の一種であるが，この回帰関数を高次 の関数に拡張したものが高次BFである．特に，1次 (平面) 関数によるBFでは階段効果が生じないことが示されている.

また, 高次BFはトリラテラルフィルタと同様に, 尾根エ ッジや谷エッジを保存するためにも用いられる.

\section{3 複合BF}

通常のBFでは入力画像は1枚だけであるが, 多重画像に もそのまま拡張される. カラー画像も, R,G,Bの3枚のモノ クロ画像からなる多重画像である。画像が $m$ 枚あるとする と, 式 (1) は

$$
f_{i k}=\frac{\sum_{j=i-p}^{i+p} e^{-\alpha(i-j)^{2}} \prod_{l=1}^{m} e^{-\beta_{l}\left(d_{i l}-d_{j l}\right)^{2}} d_{j k}}{\sum_{j=i-p}^{i+p} e^{-\alpha(i-j)^{2}} \prod_{l=1}^{m} e^{-\beta_{l}\left(d_{i l}-d_{j l}\right)^{2}}}
$$

となる. $d_{i k}$ は座標 $i の k$ 枚めの画像の画素值である. 式 (11) の多次元ガウス関数 $\prod_{l=1}^{m} e^{-\beta_{l}\left(d_{i l}-d_{j l}\right)^{2}}$ は, ベクトルの画素值間 の距離をユークリッド距離で測ることを表す。したがって, カラー画像ではCIELABなどの均等色座標が望ましい.

いろいろな撮像機器を組合せたマルチモーダル画像で は, 式 (11) は複合 (Dual) $\mathrm{BF}^{16)}$ と呼ばれ, 例えば赤外写真

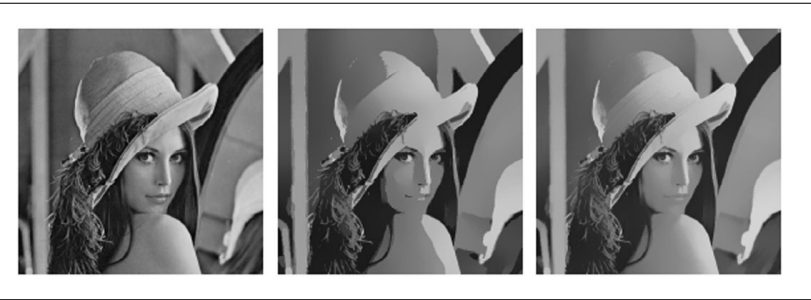

図5 左端の画像の反復BFの出力 (中央) と固定係数反復BFの出力(右)

を援用して通常写真のノイズを除去するのに応用されてい る. 複合BFは，複数の写真のエッジ情報をすべて使うの で, 通常写真では不明瞭であるようなエッジが補完され， エッジ保存性やノイズ除去能力が向上する.

また，式 (11) において $\beta_{k}=0$ とおいたもの，すなわち，あ る画像の平滑化に自身のエッジ情報ではなく, ほかの画像 のエッジ情報を用いるものをクロス (Cross) $\mathrm{BF}^{17}$ ， あるい は結合 (Joint) BF ${ }^{18)}$ と呼ぶ. これは，ある写真をノイズ除 去するときに, 他の写真のエッジ情報を利用するもので, 例えば通常写真のノイズを除去するのにフラッシュ撮影写 真を援用するのに利用されている. 図7に一例を示す. 図7 左はフラッシュなしの通常撮影, 中央はフラッシュ撮影の 写真であり, 中央の画像から計算した重み係数で左の画像 を平滑化した結果と中央の写真とを融合した結果が図7右 の画像である.

\section{4 高速化}

BFに使われているガウス関数は画像処理には有用である が，コンピュー夕処理では計算量が多い関数の一つである. したがって，ビデオなど高次元データでは計算の高速化が 望まれる.

高速化への一つのアプローチは分離可能BFである. 多次 元ガウス関数が1次元ガウス関数の積に分解されることか ら, 線形ガウスフィルタは分離可能であり, 1次元フィル 夕を逐次にかけることにより，高速に計算することができ る. BFは画素值の重みを含むため非線形であり, そのた め分離不可能であるが, 分離可能BFでBFを近似する高速 化法が提案されている ${ }^{19)}$.八イズがあまり多くない画像で, ウィンドウがそれほど広くなければ近似誤差はそれほど大 きくならないので分離可能BFは良好に㗢くが，ノイズが 増え, ウィンドウが広くなると近似誤差が増えて信頼性が 低下する。

2番目の高速化法は，3章のチャネル表現の近似に基づく もの 20 であるが，このアプローチも近似誤差が大きい.

最新のアプローチ11) は，3章で述べたバイラテラル格子 を利用して, 積空間画像を粗くサンプリングすることによ って高速化する手法である，BFは通常の画像平面表現で は非線形であるが，積空間表現でのバイラテラル格子では 線形ガウスフィルタになり，ローパス特性であることから， 積空間画像は帯域制限画像となり，かなり粗くサンプリン グしても誤差はそれほど増えないことが報告されている. この手法に加えて，GPUを活用することによってリアル夕 


\section{イム処理が可能な高速化が達成されている.}

\section{5 非等方BF}

2章で述べたように，BFは画素值方向の重みを含むことに よって自動的に空間非等方になるが，画像平面方向の重み $e^{-\alpha(i-j)^{2}}$ を非等方に拡張した非等方BFが提案されている ${ }^{21)}$. 非 等方BFは, 線状模様を保存してノイズ除去するのに適し ているが, 非等方性を誇張することによって, 手描き風の 線状模様を画像に付けるのにも利用されている. この非等 方フィルタは, イラスト風画像での滑らかな輪郭線を得る のにも利用される.

\section{6 ウィンドウBF}

式 (1) の画素值軸方向の重み $e^{-\beta\left(d_{i}-d_{j}\right)^{2}}$ は画素值 $d_{i}$ と $d_{j}$ の類 似度である。これを, 座標 $i$ 中心とするウィンドウ $[i-q$, $i+q]$ と $j$ 中心のウィンドウ $[j-q, j+q]$ の類似度

$$
e^{-\beta \sum_{k=-q}^{q} e^{-\gamma k^{2}}\left(d_{i+k}-d_{j+k}\right)^{2}}
$$

に拡張したものをウィンドウBFと呼ぶ. $\gamma$ 大きくすると ウィンドウBFは通常のBFに近づく．通常のBFは画素単位 の類似度なので，テクスチャもノイズとみなされて平滑化 され, イラスト風画像の生成ではそれが画像の単純化に利 用されるが，医用画像などではテクスチャを保存すべき場 合も多い. ウィンドウBFはウィンドウ単位の類似度なの で，空間的な相関をもつテクスチャの保存性が高まり，空 間相関が低いノイズの除去能力が向上する. 式 (12) を式 (1)に代入したウィンドウBFにおいて, $\sum_{j=i-p}^{i+p}$ を画像全体 にしたもの，すなわち，類似領域を画像全体のなかから探 すのを非局所平均フィルタ 22$)$ という. その際, 式 (1)の $\alpha$ は0にすることが多い.

このようにウィンドウBFは優れたノイズ除去性能をもつ が，計算量が多いのが難点であり，前章で述べたような高 速化法がウィンドウBFについても望まれる.

\section{7. 応用}

BFの主な応用は，ノイズが加わった画像からノイズを除 去するものであるが，ノイズのない画像を対象としても 種々の利用法が提案されてきている.

\section{1 ノイズ除去}

$\mathrm{BF}$ は医用画像のノイズ除去など基本的な応用から，オプ

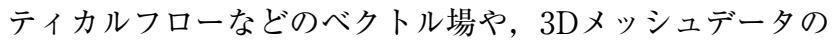
平滑化など広範囲の空間デー夕の精製に利用されている. BFは，ガウス関数すなわちユークリッド距離を基本とす るが，オプティカルフローの速度場や3D物体表面の法線べ クトル場などの類似度は, ユークリッド距離では測れない ので注意が必要である。また最近では複合BFなど，種々 の撮像機器を活用した画像処理法への応用が盛んになって きている.

\section{2 画像のイラスト化}

画像のイラスト化では，イラスト風トーンの画像生成と エッジ抽出が用いられる。すなわち, 入力画像のコントラ
ストの高いエッジは保存し，コントラストが低い領域はさ らに低くして，トーンを簡略化した画像に主要エッジを上 描きしてイラスト風画像を生成する。このトーンの簡略化 にBFが適している。 またエッジも, 平滑化してから抽出 するほうが，不要な微細エッジが除去されて主要エッジだ けが残り，手描きの輪郭線に近いエッジが得られる。この とき，1回のBFだけでは画像の簡略化が不充分なため，数 回反復してBFがかけられることが多いが，6.2節でも述べ たように通常の反復BFでは擬似輪郭が生じることがある.

擬似輪郭の原因となる階段効果を解消する手法として, 6.2節の高次BFなどがあるが，処理が煩雑である．擬似輪 郭を緩和する簡便な手法としては，式 $(7) の e^{-\beta\left(f_{i}^{(\mu)}-f_{j}^{(\mu)}\right)^{2}}$ を $e^{-\beta\left(d_{i}-d_{j}\right)^{2}}$ に変えた

$$
f_{i}^{(\mu+1)}=\frac{\sum_{j=i-p}^{i+p} e^{-\alpha(i-j)^{2}} e^{-\beta\left(d_{i}-d_{j}\right)^{2}} f_{j}^{(\mu)}}{\sum_{j=i-p}^{i+p} e^{-\alpha(i-j)^{2}} e^{-\beta\left(d_{i}-d_{j}\right)^{2}}}
$$

を反復する方法がある. これは式 $(10)$ の最初の $d_{j}$ を $f_{j}$ に変 えた

$$
\min _{f} \sum_{j=i-p}^{i+p}\left(f_{i}-f_{j}\right)^{2} e^{-\alpha(i-j)^{2}} e^{-\beta\left(d_{i}-d_{j}\right)^{2}}
$$

の反復解法である.この手法では反復BFの重み係数が入 力画像での值に固定されるので, 入力画像の保存性が高く, 図5右端に示すように，イラスト風エッジ抽出に適した平 滑化が行える.

このような平滑化された画像から手描き風のエッジを抽 出するには，ソーベルフィルタなどの差分フィルタよりも， 自己商画像の 2 值化による方法が適している．自己商画像 とは, 入力画像の画素值を，それを平滑化した画像の画素 值で割った值 (すなわち商) を画素值とする画像である。こ の商の值がしきい值，例えば，0.9よりも小さくなる画素を エッジとして取出せば，画像の暗い部分でもエッジを検出 することができる ${ }^{23)}$. このエッジ検出法において，自己商 画像や検出エッジ画像に非等方BFをかけると, エッジが 滑らかになり，より手描き風になる。

図5右端の画像のエッジを非等方BFで平滑化したものを 図5右端の画像に上描きしたイラスト風画像を図6に示す. このようなイラスト画像のパターン認識への応用例とし

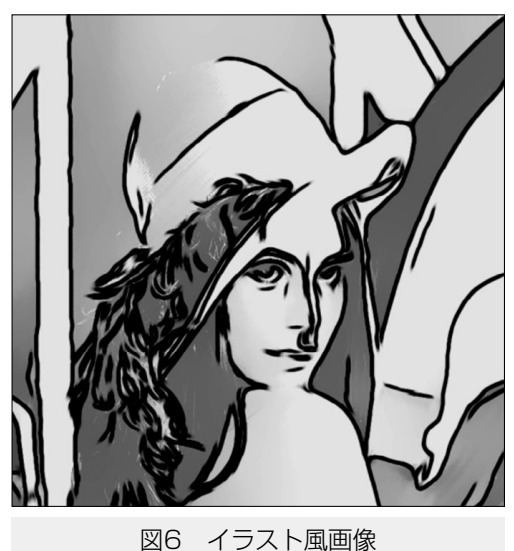

映像情報メディア学会誌 Vol. 62, No. 8 (2008) 


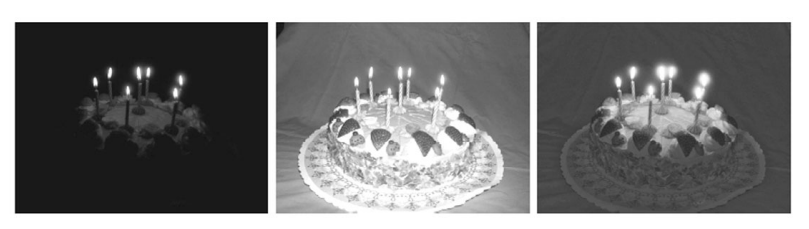

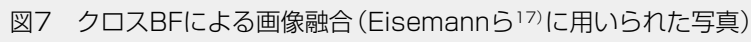

て, 顔画像をそのまま被験者に認識させるよりも, イラス 卜化したほうが認識が速いという報告例がある24)。また， CG画像と実写画像を合成する拡張現実感において, 合成 の違和感を緩和するために, 実写画像をイラスト化する手 法が提案されている.

\section{3 トーン調整}

写真での画素值は, 照明の輝度と物体の反射率の積であ り, 多くの場合, 照明の空間的な変化は緩やかであり, そ れに比べてテクスチヤによる反射率は細かく変化する。こ の性質に基づいて，画像を低周波の照明成分と高周波のテ クスチャ成分に分離して，画像のトーンを調整する手法が 提案されている. 積を和に直すために画素值の対数をとり， BFをかけた出力を照明成分とし，残差をテクスチャ成分 とする。

照明成分のレンジを圧縮すれば，暗いところのコントラ ストを上げることができ ${ }^{25)}$ ，より一般に照明成分を調整す ることによりリライティング (Relighting) が行える17). ま たテクスチャ成分も調整する高機能なトーン調整法が提案 されている26.

画像にBFをかけて低周波の基調成分を求め, 残差の詳細 成分との和に分解する手法は, ダイナミックレンジ圧縮で のコントラスト改善の他にも, 多重画像の融合など広範に 利用されている．BFによる画像の周波数成分分離の長所 は，線形フィルタによる分離で生じるエッジ付近の人工的 なハローが生じないことである. 図7左と中央の2枚の写真 を融合して図7右のような画像を合成するときなどに，こ のような画像融合法が使える.

\section{8.むすび}

本稿では最近利用範囲が広がりつつあるBFについて，基 礎的な事項を説明し, 数多く提案されている拡張や応用例 などを紹介した．アルゴリズムとしては，比較的最近に提 案されたウィンドウBFの今後の発展に興味が持たれる. また応用面では，高速な実装によりカメラによるイラスト 風似顔絵生成や高機能なトーン調整などが期待される.

(2008年2月27日受付)

\section{〔文 献〕}

1) S. Smith and J. Brady: "SUSAN - A New Approach to Low Level Image Processing", Int. J. Comput. Vision, 23, 1, pp.45-78 (1997)
2) V. Aurich and J. Weule: "Non-linear Gaussian Filters Performing Edge Preserving Diffusion", Proc. DAGM Symp., pp.538-545 (1995)

3) C. Tomasi and R. Manduchi: "Bilateral Filtering for Gray and Color Images", Proc. ICCV, pp.839-846 (1998)

4) J.-S. Lee: "Digital Image Smoothing and the Sigma Filter", CVGIP, 24 , pp.255-269 (1983)

5) G.F. Dominguez, H. Bischof and R. Beichel: "Fast 3D Mean Shift Filter for CT Images", Proc. SCIA, pp.438-445 (2003)

6) C. Liu, W.T. Freeman, R. Szeliski, and S. Kang: "Noise Estimation from a Single Image", Proc. CVPR, pp.901-908 (2006)

7) N. Sochen, R. Kimmel, and R. Malladi: "A General Framework for Low Level Vision", IEEE Trans. Image Proces., 7, pp.310-318 (1998)

8) M. Felse, P.-E. Forssen, and H. Scharr: "Channel Smoothing: Efficient Robust Smoothing of Low-Level Signal Features", IEEE Trans. Patt. Anal. Mach. Intell., 28, 2, pp.209-222 (2006)

9) J. Koenderink and A. Van Doorn: "The Structure of Locally Orderless Images", Int. J. Comput. Vision, 31, pp.159-168（1999）

10) T.Q. Pham: "Spatial Adaptivity in Super-Resolution of Undersampled Image Sequences", Ph.D. Thesis, Delft Univ. Tech. (2006)

11)S. Paris and F. Durand: "A Fast Approximation of the Bilateral Filter Using a Signal Processing Approach", Proc. ECCV, pp.568-580 (2006)

12) 岡田正之, 浦浜喜一：“モードフィルタによるカラー画像のエッジ保 存平滑化”，信学論，J81-A, 8, pp.1189-1191（1998）

13) R. Garnett, T. Huegerich, C. Chui, and W. He: "A Universal Noise Removal Algorithm with An Impulse Detector", IEEE Trans. Image Process., 14, 11, pp.1747-1754 (2005)

14)P. Choudhury and J. Tumblin: "The Trilateral Filter for High Contrast Images and Meshes", Proc. EGSR, pp.186-196 (2003)

15) A. Buades, B. Coll, and J.-M. Morel: "The Staircasing Effect in Neighborhood Filters and Its Solution", IEEE Trans. Image Process. 15, 6, pp.1499-1505 (2006)

16) E. Bennett, J. Mason, L. McMillan: "Multispectral Bilateral Video Fusion", IEEE Trans. Image Process., 16, 5, pp.1185-1194 (2007)

17)E. Eisemann and F. Durand: "Flash Photography Enhancement Via Intrinsic Relighting", ACM Trans. Graph., 23, 3, (July 2004)

18) G. Petschnigg, M. Agrawala, H. Hoppe, R. Szeliski, M. Cohen, and K. Toyama: "Digital Photography with Flash and No-Flash Image Pairs", ACM Trans. Graph., 23, 3 (July 2004)

19) T. Q. Pham and L. J. van Vliet: "Separable Bilateral Filtering for Fast Video Preprocessing", Proc. ICME (2005)

20) B. Weiss: "Fast Median and Bilateral Filtering", ACM Trans. Graph., 25, 3, pp.519-526 (2006)

21)井上光平, 浦浜喜一：“非等方バイラテラルフィルタによるエッジ保 存縞模様強調”，映情学誌，58，1，pp.115-120（2004）

22) A. Buades, B. Coll, and J.M. Morel: "A Review of Image Denoising Algorithms with a New One", Multiscale Model. Simul., 4, 2, pp.490530 (2005)

23) 景琳琳，井上光平，浦浜喜一：“自己商画像の非等方平滑化に基づく イラスト風画像”，信学論，J89-A，5，pp.385-386（2006）

24) H. Winnemoller, S.C. Olsen, and B. Gooch: "Real-Time Video Abstraction", ACM Trans. Graph., 25, 3, pp.1221-1226 (2006)

25)F. Durand and J. Dorsey: "Fast Bilateral Filtering for the Display of High-Dynamic-Range Images", ACM Trans. Graph., 21, 3 (2002)

26) S. Bae, S. Paris, and F. Durand: "Two-Scale Tone Management for Photographic Look", ACM Trans. Graph., 25, 3, pp.637-645 (2006)

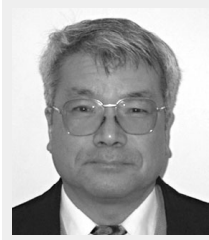

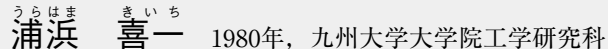
博士後期課程修了. 同年, 同大学助手. 1989年, 九州 工業大学助教授. 現在, 九州大学大学院芸術工学研究 院教授. パターン認識, 画像情報処理の研究に従事. 